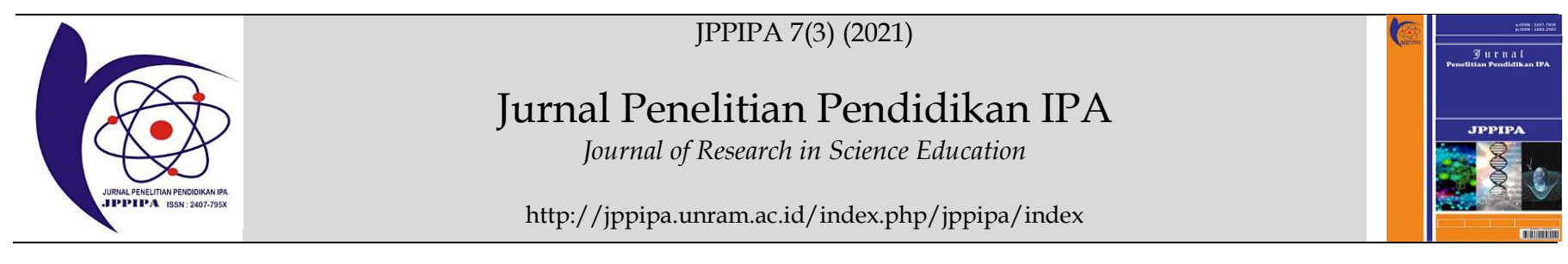

\title{
The Role of Biochar and Combination of Inorganic Fertilizers and Biological Fertilizers in Increasing Yield and Levels of Brix Sorghum (Sorghum bicolor (L.) Moench) in Dry Land
}

\author{
Hadromy Hawari ${ }^{1}$, Suwardji ${ }^{1,2^{*}}$, Husni Idris ${ }^{3}$ \\ ${ }^{1}$ Master's Program in Dry Land Agriculture, Postgraduate Program at Mataram University, Mataram, Indonesia \\ ${ }^{2}$ Soil Science Study Program, Faculty of Agriculture, University of Mataram, Mataram, Indonesia \\ ${ }^{3}$ Forestry Study Program, Faculty of Agriculture, Mataram University, Mataram, Indonesia
}

DOI: $10.29303 /$ ippipa.v7i3.729

\section{Article Info}

Received : April 30th 2021

Revised : July 5th, 2021

Accepted: July 12th, 2021

\begin{abstract}
Research on the role of biochar, inorganic and biological fertilizers was aimed to increase crop yield and brix value of sorghum in dryland. This research was conducted from October 2020 to February 2021 at The Teaching Farm Soil Science Study Program, Akar-Akar Village, Bayan, North Lombok. The method used in this research is an experimental method, with the experimental plot in the field. The experiment consisted of two factors, was designed using a split-plot design. Biochar as the main plot with 2 treatment levels, $b_{0}$ (without biochar) dan $b_{1}$ (biochar 20 ton/ha); combination of fertilization as subplots with 4 treatment levels, namely $\mathrm{p}_{0}$ (without fertilizer), p1 (200 kg/ha NPK $+150 \mathrm{~kg} / \mathrm{ha}$ Agrosil), $\mathrm{p}_{2}$ $\left(20 \mathrm{ml} /\right.$ liter PGPR), and $\mathrm{p}_{3}(200 \mathrm{~kg} / \mathrm{ha} \mathrm{NPK}+150 \mathrm{~kg} / \mathrm{ha}$ Agrosil $+20 \mathrm{ml} / \mathrm{L} \mathrm{PGPR})$. The research showed that interaction between biochar and combination of fertilizers is not significant, but the combination of inorganic and biological fertilizers significantly increased sorghum's productivity and brix value. The combination of inorganic and biological fertilizer $\left(p_{3}\right)$ is the best treatment to increase weights 1000 seeds $(31.29 \mathrm{~g})$, yield (25.96 kg/plot), and brix value $(14.55 \%)$
\end{abstract}

Keywords: Biochar; Inorganic Fertilizer; Organic fertilizer; Sorghum

Citation Hawari, H., Suwardji, S., \& Idris, H. (2021). The Role of Biochar and Combination of Inorganic Fertilizers and Biological Fertilizers in Increasing Yield and Levels of Brix Sorghum (Sorghum bicolor (L.) Moench) in Dry Land. Jurnal Penelitian Pendidikan IPA, 7(3), 437-442. doi:https://doi.org/10.29303/jppipa.v7i3.729

\section{Introduction}

Sorghum (Sorghum bicolor (L.) Moench) is a plant that has the potential to be developed in dry land as an alternative food commodity because it is resistant to drought stress and requires less water $(420-500 \mathrm{~mm})$ compared to maize $(600-670 \mathrm{~mm})$ (Sonobe et al., 2011; FAO, 2012). This plant is also called a multi-purpose plant because all parts of the plant can be utilized. Apart from being a source of food, sorghum can be used as animal feed and as a raw material for bioethanol (Pabendon et al., 2013; Zubair, 2016; Cole et al., 2016)

Sweet sorghum is one type of sorghum that has the potential to be developed in the dry land of North Lombok because of its wide adaptability (Silva et al.,
2016) and its more multi-purpose nature than other types of sorghum (The advantage of sweet sorghum is that it can be extracted when the sap is taken from the sorghum stalk, and can then be used for various purposes, including a source of raw alcohol for alternative fuels (Zubair, 2016).

Sweet sorghum cultivation in the dry land of North Lombok Regency is still not optimal. Its productivity can even be said to be relatively low. Besides the inherent factors, namely the lack of support for dry land biophysical constraints, the low productivity of sorghum and other food crops cultivation, it is also caused by the lack of understanding of farmers about farming systems in dryland and the limited touch of appropriate conservation technology. 
The results of previous studies show that the productivity of sorghum in dry land is still relatively low (1.5-3 tons/ha) (Suwardji et al., 2019) compared to the international productivity of sorghum which can reach 6-9 tons/ha (FAO, 2010; FAO, 2013).

In connection with these constraints, it is necessary to engineer technology to increase the productivity of land and sorghum plants in a sustainable manner in the dry land of West Nusa Tenggara. Provision of soil improvement materials is one alternative that can be done to overcome obstacles to agricultural development in a dry land, especially sandy soil. The addition of organic ingredients such as compost and manure has been done a lot, but it becomes inefficient because it is needed in large quantities and does not last long (Nurida, 2013).

Biochar is biological charcoal resulting from burning organic biomass in limited oxygen conditions as an alternative soil improvement agent that can accelerate soil quality improvement in dryland (Gusmailina et al., 2015). Biochar is able to last a long time in the soil or is relatively resistant to soil microorganism attacks compared to other repairing materials so that the decomposition process runs slowly (Tang et al., 2013). The source of biochar raw material that can be used is coconut shell. The percentage of biochar produced is indeed lower when compared to other raw materials such as oil palm shells and rice husks, but the use of coconut shell biochar has the potential to be applied by farmers because of the abundance of raw materials. The water retention ability of coconut shell biochar is also higher than that of cocoa pod husk and rice husk biochar. The results of research on the use of coconut shell biochar have been shown to be able to increase soil and maize, and sorghum productivity (Suwardji et al., 2011; Sukartono et al., 2015; Adiansyah, 2017).

Efforts to improve soil quality and crop yields in a dry land, of course, cannot only use biochar. This is because biochar is not a fertilizer. In addition, the capacity of dry land to support nutrient fulfillment for plants is very low, so that fertilization activities are still needed, especially integrated fertilization, namely fertilization that combines organic and inorganic fertilizers. The results of research reinforce this by Fischer and Glaser (2012) and Kammann et al. (2016), which states that biochar is more effective when combined with organic repairing materials such as compost, manure, inorganic fertilizers, and biological fertilizers.

The combination of fertilizers that can be applied in integrated fertilization is Plant Growth Promoting Rhizobacteria (PGPR) biological fertilizer with NPK and Agrosil fertilizers. PGPR fertilizer is a biological fertilizer that can stimulate plant growth and biological control that can increase plant resistance to plant pest organisms (OPT), especially fungi. NPK fertilizer is a compound inorganic fertilizer that can provide plant needs for N, P, and K nutrients, so that the use of urea, SP-36, and $\mathrm{KCl}$ fertilizers can be reduced (Kaya, 2013). Aerosil fertilizer is a fertilizer that contains silica (Si). Silica is an element that is needed by sorghum because sorghum is one of the $\mathrm{Si}$ accumulators' plants that can increase tolerance to abiotic stress (Sonobe et al., 2011). The combination of fertilization is expected to increase the growth and yield of sweet sorghum because the results of research by Suwardji et al. (2019) reported that NPK and Si fertilization were able to increase sorghum yields $>87 \%$ to $>6.48$ tons $/$ ha.

The packaged technology engineering is expected to be a technology recommendation for sorghum cultivation that can increase production $>7$ tons/ha.

\section{Method}

The method used in this study is an experimental method with plot experiments in the field. This research was conducted in October 2020-February 2021 at the Teaching Farm of the Soil Science Study Program, AkarAkar Village, Bayan District, North Lombok Regency. The flow of the research implementation can be seen in Figure 1.

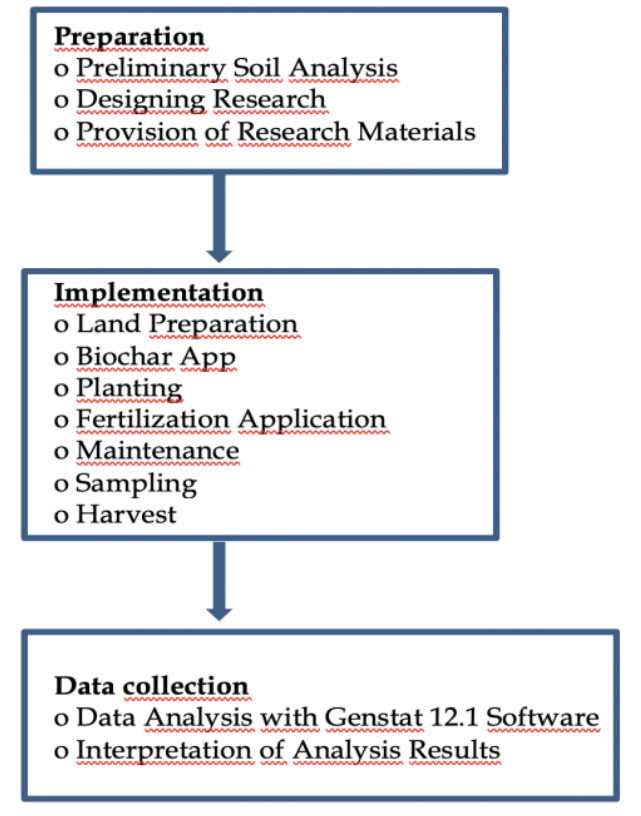

Figure 1. Research Flowchart

\section{Research Tools and Materials}

The tools used in this research are digital scales, analytical scales, meters, portable refractometers, squeezers, and tools for analysis in the laboratory. The materials used were sorghum seeds of Samurai 2 variety, coconut shell biochar, NPK fertilizer (Phonska 
15:15:15), Korean Agrosil fertilizer ( $\mathrm{SiO} 2$ 25\%), PGPR biological fertilizer from BPTPH NTB, aquades, and materials for laboratory analysis.

\section{Experimental design}

The experiment consisted of two factors which were designed using a split-plot design, namely:

1. Treatment or Biochar factor (B) as the main plot consists of two levels, namely: (1) No Biochar application (b0); (2) Biochar application at a dose of 20 tons/ha (b1).

2. The treatment or combination of fertilization factors (P) as sub-plots consisted of 4 levels, namely: (1) No fertilizer (p0); (2) $200 \mathrm{~kg} /$ ha NPK Phonska inorganic fertilizer and $150 \mathrm{~kg} / \mathrm{ha}$ Agrosil (p1); (3) PGPR biological fertilizer $20 \mathrm{ml} /$ liter (p2); (4) $20 \mathrm{ml} /$ liter PGPR biological fertilizer $+200 \mathrm{~kg} /$ ha inorganic fertilizer Phonska NPK and $150 \mathrm{~kg} /$ ha. Agrosil (p3) Each treatment will be repeated four times to obtain 32 experimental units with an area of $36 \mathrm{~m}^{2}$ each.

\section{Preparation}

\section{Preliminary Soil Analysis}

This analysis was conducted to determine the conditions and characteristics of the soil in the experimental field, particularly the chemical properties of the soil such as total $\mathrm{N}(\%)$, available $\mathrm{P}$ (ppm), available $\mathrm{K}$ (ppm), $\mathrm{pH}$, and organic $\mathrm{C}(\%)$.

\section{Provision of PGPR Biofertilizer}

PGPR biofertilizer was obtained from the Center for Agricultural Crop Protection, West Nusa Tenggara.

\section{Preparation of Biochar}

The biochar used is biochar made from coconut shells obtained from Bengkaung Village, Batulayar District, West Lombok Regency.

\section{Seed Preparation}

The sweet sorghum seeds used in this study were the Samurai 2 variety obtained from the National Nuclear Energy Agency (BATAN).

\section{Land supply}

The required land area is calculated based on the spacing and the number of experimental plots. The plot area used in this study was $36 \mathrm{~m} 2(6 \times 6) \mathrm{m}^{2}$, with a spacing of $(100 \times 25) \mathrm{cm}^{2}$ (Zubair, 2016).

\section{Trial Execution}

\section{Land Preparation}

Land preparation is done two weeks before planting. The land is plowed with tractors to remove weeds and previous crop residues and improve soil texture. After that, 32 experimental plots were made,

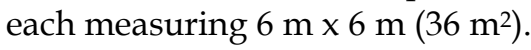

\section{Biochar Treatment Application}

Biochar is given by being stocked and mixed at the time of processing and making experimental plots with the application dose adjusted to the treatment, namely the dose of 0 tons/ha or without the application of biochar (b0) and the application of biochar 20 tons/ha (b1)

\section{Seed Preparation and Planting}

Making planting holes is done by tugal with a spacing of $100 \times 25 \mathrm{~cm}$. Seeds are inserted into the planting hole with the amount of 5 seeds per hole. After the plants grew, thinning was carried out, leaving one of the healthiest plants at the age of 14 HST.

\section{Fertilizer Application}

The application of fertilization is adjusted to the treatment plan, namely: (1) No fertilizer application (p0); (2) The application of inorganic fertilizer (p1) is 200 $\mathrm{kg} / \mathrm{ha}$ NPK Phonska and $150 \mathrm{~kg} / \mathrm{ha}$ Agrosil. This treatment will be given two times at 14 and 40 HST with a half dose at each time of application by means of a tube with a depth of $5 \mathrm{~cm}$; (3) Application of biological fertilizer PGPR (p2), with a dose of $20 \mathrm{ml} /$ liter will be applied at the time of soaking the seeds, 7, 14, 21, and 28 HST. Soaking will be carried out for 12 hours before planting, while at the age of 7, 14, 21, and 28 HST, it will be applied by spraying using a hand sprayer; (4) Application of $20 \mathrm{ml} /$ liter PGPR biological fertilizer and inorganic fertilizer $(200 \mathrm{~kg} / \mathrm{ha}$ NPK + $150 \mathrm{~kg} / \mathrm{ha}$ Agrosil) (p3)

\section{Maintenance \\ Irrigation}

At the beginning of growth, sorghum is a drought-resistant plant, but it is very responsive to watering. The critical period is during germination, flowering, and seed filling. Soil moisture conditions are maintained until germination. Irrigation is carried out in 2-3 days depending on soil moisture conditions with a sprinkler irrigation system for 2 hours.

\section{Weeding}

Weeding is done manually with a hoe or sickle. The intensity of weeding depends on the speed at which weeds grow in the planting area. The first wedding was done before the first fertilization at 10 HST. Second wedding before the second fertilization at 30 HST. Subsequent weeding when the plant enters the generative phase. 


\section{Hoarding}

Hoarding done simultaneously with the second weeding ( $30 \mathrm{HST}$ ). Bumping is done by loosening the soil around the plant, then piling the soil at the base of the stem to stimulate root growth and strengthen the plant so that it does not fall easily.

\section{HPT Control}

Pest and disease control is carried out if the plants show symptoms of attack. The method and timing of control depends on the type of pests and diseases that attack the crop.

\section{Determination of Plant Examples}

a. Observation of brix levels

Plants that were used as samples were determined randomly outside the tile plots as much as $5 \%$ of the population per experimental plot, namely seven plant samples per observation time.

b. Production Observation

Plants used as examples for yield are in tiles with a size of $(3 \times 2.25) \mathrm{m}$.

\section{Harvest}

Harvesting is done when the sorghum seeds are old enough, pithy, and hard, namely when the plant is 113 HST.

\section{Research variable}

1. Weight 1000 seeds (g)

The weight of 1000 seeds was obtained by weighing 1000 grains of sorghum seeds harvested from the tile plots.

\section{Production yield per plot}

The yield per plot is obtained from the conversion of tile weight according to Purwanto et al. (2014) with the equation:

$$
\begin{aligned}
& N=\frac{U 1+U 2+U 3+U 4}{4} \operatorname{kg} x \frac{36}{3 \times 2,25} \\
& \mathrm{~N} \quad \text { : Production per plot } \\
& \text { U1 : } 1 \text { replicate tile weight } \\
& \text { U2 : } 2 \text { replicate tile weight } \\
& \text { U3 : } 3 \text { replicate tile weight } \\
& \text { U4 : } 4 \text { replicate tile weight } \\
& 36 \text { : Plot area } \\
& 3 \times 2.25 \text { : Tile area }
\end{aligned}
$$

\section{brix level}

The measurement of brix levels was carried out starting from the $50 \%$ flowering phase, namely when the plants were $\pm 63 \mathrm{HST}$ at intervals of every 14 days and at harvest using a portable refractometer brix in the field.

\section{Data analysis}

All observational data have been analyzed using Analysis of Variance (ANOVA) with Genstat 12.1 Program. If the ANOVA results are significantly different, then it is continued with the honest significant difference test (HSDT) at the $5 \%$ level.

\section{Result and Discussion}

\section{Characteristics of the Experimental Ground}

Table 1. Characteristics of the Experimental Land

\begin{tabular}{llll}
\hline No & Soil Properties & Values & Criteria \\
\hline 1 & pH H2O & 6.04 & A bit sour \\
2 & N-Total (\%) & 0.13 & Low \\
3 & P-Available Bray (ppm) & 52.61 & High \\
4 & K-Available Morgan (ppm) & 86.23 & Very high \\
5 & C-Organic & 1.15 & Low \\
\hline
\end{tabular}

Note: The analysis was carried out at the BPTP Laboratory of the Province of West Nusa Tenggara.

The results of the laboratory analysis of the soil characteristics (Table 1) showed that the soil $\mathrm{pH}$ in the experimental field (6.04) was slightly acidic. This condition is considered ideal for sorghum growth because it is in the optimum $\mathrm{pH}$ range for its growth, namely 5.5-7.5 (Djaenudin et al., 2011; Zubair, 2016). The levels of N-Total and organic $C$ were in a low condition, while P-available and K-available were included in the high and very high criteria. N-Total and C-Organic are included in the low criteria, while the levels of available $\mathrm{P}$ and available $\mathrm{K}$ are included in the high and very high criteria, respectively.

\section{Production result}

Table 2. Average Yield of Seed Production and Weight of 1000 Seeds

\begin{tabular}{llll}
\hline No & Perlakuan & Results (kg/plot) & Bobot 1000 biji (g) \\
\hline 1 & $\mathrm{p}_{0}$ & $7,92^{\mathrm{a}}$ & $23,94^{\mathrm{a}}$ \\
2 & $\mathrm{p}_{1}$ & $19,48^{\mathrm{b}}$ & $28,56^{\mathrm{c}}$ \\
3 & $\mathrm{p}_{2}$ & $15,29^{\mathrm{b}}$ & $26,66^{\mathrm{b}}$ \\
4 & $\mathrm{p}_{3}$ & $25,96^{\mathrm{c}}$ & $31,29^{\mathrm{d}}$ \\
& HSDT 5\% & 6.95 & 2.249 \\
\hline
\end{tabular}

Note: Numbers followed by the same letter in the same column are not significantly different in the HSDT 5\%.

The results of the analysis of variance showed that there was no significant interaction between biochar and combination of fertilization on yield and weight of 1000 seeds, but biochar and combination of fertilization independently gave significantly different effects on yield and weight of 1000 seeds. The data in Table 2 shows that the highest average grain yield was obtained in the p3 treatment of $25.96 \mathrm{~kg} /$ plot or equivalent to 7.21 tons/ha; followed by $\mathrm{p} 1(19.48 \mathrm{~kg} /$ plot equivalent to 5.41 tons/ha), p2 $(15.29 \mathrm{~kg} /$ plot equivalent to 4.25 tons/ha), and p0 $(7.92 \mathrm{~kg} /$ plot equivalent to 2.20 
tons/ha). The experimental results showed that the highest mean weight of 1000 seeds was obtained in the p3 treatment, which was $31.29 \mathrm{~g}$; followed by p1 (28.56 g), p2 (26.66 g), and p0 (23.94 g).

According to the variety description by Batan, the weight of 1000 sorghum seeds of Samurai 2 variety is \pm $27.4 \mathrm{~g}$ with a potential yield of 8.5 tons/ha, and an average yield of \pm 6.4 tons/ha. The weight of 1000 seeds in this study was higher than their potential, namely $31.29 \mathrm{~g}(\mathrm{p} 3)$ and $28.56 \mathrm{~g}$ (p1). The yield potential has not yet been achieved, but the data shows that the production yield in the $\mathrm{p} 3$ treatment (equivalent to 7.21 tons/ha) is greater than the average yield potential of \pm 6.4 tons. The high yield and weight of 1000 seeds in p3 treatment compared to other treatments was due to the role of inorganic fertilizers (NPK and Agrosil) and biological fertilizers (PGPR). The addition of inorganic fertilizers can increase the supply of $\mathrm{N}, \mathrm{P}, \mathrm{K}$, and $\mathrm{Si}$ nutrients needed by sorghum plants to grow and produce optimally. PGPR acts as PGR, which can stimulate the growth and dissolution of P-inorganic by Pseudomonas fluorescens and Bacillus subtilis bacteria contained in PGPR through the production of $\mathrm{CO}_{2}$ and organic acids. This is supported by the research results of Istiqomah et al. (2017), who concluded that B. subtilis and $\mathrm{P}$. fluorescens have the potential to dissolve phosphate and produce IAA, which can increase plant growth.

\section{Brix rate}

The results of the analysis of variance showed that there was no interaction between biochar and combination fertilization. The combination of inorganic fertilizers and biological fertilizers independently significantly affected the value of brix levels in each observation.

Table 3. Average Brix Levels Per Observation Time

\begin{tabular}{|c|c|c|c|c|c|}
\hline \multirow{3}{*}{ Treatment } & \multicolumn{5}{|c|}{ Brix rate $(\%)$} \\
\hline & 63 & 77 & 91 & 105 & PANIFN \\
\hline & HST & HST & HST & HST & PAINEN \\
\hline $\mathrm{p}_{0}$ & $4.69^{a}$ & $6.15^{a}$ & $6.29 a$ & $10.35^{a}$ & $9.35^{\mathrm{a}}$ \\
\hline $\mathrm{p}_{1}$ & $7.44^{\mathrm{bc}}$ & $8.83^{b c}$ & $11.07 \mathrm{bc}$ & $12.34^{\mathrm{ab}}$ & $10.98^{a b}$ \\
\hline $\mathrm{p}_{2}$ & $7.17 \mathrm{~b}$ & $8.03^{\mathrm{b}}$ & $10.21^{\mathrm{b}}$ & $11.26^{\mathrm{ab}}$ & $9.73^{a}$ \\
\hline $\mathrm{p}_{3}$ & $7.91^{c}$ & $9.80^{c}$ & $13.14^{\mathrm{c}}$ & $14.55^{\mathrm{b}}$ & $12.40^{\mathrm{b}}$ \\
\hline HSDT 5\% & 0.696 & 1.599 & 2.82 & 3.34 & 2.38 \\
\hline
\end{tabular}

Note: Numbers followed by the same letter in the same column are not significantly different in the $5 \%$ HSDT test

The data in Table 3 shows that the p3 treatment has the highest mean value of brix levels compared to other treatments at each observation time. The data also showed the same trend in each treatment, namely the lowest brix content value at 63 DAP observations, then an increase in the next observations $(77,91,105$ DAP and harvest). The highest value of brix content occurred at 105 DAP observations and decreased at harvest (113 DAP).

The results have also shown that the addition of fertilizer (p1, p2, p3) or not (p0), the value of brix sorghum Samurai 2 can reach its potential of $\pm 7.8 \%$. The use of fertilizers, of course, will increase the value of brix levels, mainly due to the influence of Potassium (NPK) and Silicate (Agrosil), through the mechanism of suppressing the activity of the enzymes invertase, peroxidase, polyphenol oxidase, phosphatase, and adinosintriphosphatase in stems. Reduction of phosphatase activity provides a greater supply of essential high energy required for optimal sugar growth and production. This is in line with the research results of Apliza et al. (2020), who concluded that the addition of Si fertilizer could significantly increase the yield and brix content of sorghum.

\section{Conclusion}

Based on the results and discussions that have been carried out, it can be concluded that there is no interaction between biochar and the combination of fertilizers, but the combination of fertilizers independently has a significant effect on 1000 seed weight, yield, and brix content of sorghum. The combination of inorganic fertilizer and biological fertilizer (p3) was the best treatment in increasing the weight of 1000 seeds (31.29 g), production yield (25.96 $\mathrm{kg} / \mathrm{plot}$ ) equivalent to 7.21 tons/ha and brix content $(14.55 \%)$, so that engineering cultivation technology that produces $>7$ tons/ha can be achieved.

\section{References}

Adiansyah (2017). Respon Pertumbuhan Bobot Kering Panen dan Hasil Tanaman Sorgum akibat Pemberian Bahan Pembenah Tanah dan Penerapan Sistem Irigasi di Lahan Kering Lombok Utara (Tesis). Universitas Mataram, Indonesia. [Indonesian]

Apliza, D., Ma'shum, M., Suwardji, S., \& Wargadalam, V. (2020). Pemberian Pupuk Silikat dan Pupuk Kandang Terhadap Pertumbuhan, Kadar Brix, dan Hasil Tanaman Sorgum (Sorghum bicolor (L.) Moench). Jurnal Penelitian Pendidikan IPA, 6(1), 1624. doi:https://doi.org/10.29303/jppipa.v6i1.229 [Indonesian]

Cole, M. R., Eggleston, G., Petrie, E., Uchimiya, S. M., \& Dalley, C. (2017). Cultivar and maturity effects on the quality attributes and ethanol potential of sweet sorghum. Biomass and Bioenergy, 96, 183192. 
https://doi.org/https://doi.org/10.1016/j.biom bioe.2016.12.001

Djaenudin, D., Marwan, H., Subagjo, H., dan A. Hidayat. (2011). Petunjuk Teknis Evaluasi Lahan Untuk Komoditas Pertanian. Balai Besar Litbang Sumberdaya Lahan Pertanian, Badan Litbang Pertanian, Bogor. 36p. [Indonesian]

FAO (2012). Crop Yield Respon to Water. FAO Irrigation and Drainage Paper 66: 144-154.

FAO (2013). The State of Food Insecurity in The World. Rome : The United Nations

Fischer, D. dan Glaser, B. (2012). Synergisms between Compost and Biochar for Sustainable Soil Amelioration. Management of Organic Waste: 168198.

Gusmailina, Komarayati, S., dan Pari, G. (2015). Membangun Kesuburan Lahan dengan Arang. Bogor: Pusat Penelitian dan Pengembagan Hasil Hutan Badan Penelitian, Pengembangan, dan Inovasi Kementerian Lingkungan Hidup dan Kehutanan. [Indonesian]

Istiqomah, Aini, L. Q. \& Abadi, A. L. (2017). Kemampuan Bacillus subtilis dan Pseudomonas fluorescens dalam Melarutkan Fosfat dan Memproduksi Hormon IAA (Indole Acetic Acid) untuk Meningkatkan Pertumbuhan Tanaman Tomat. Buana Sains Vol 17 No 1 : 75-84. doi: https://doi.org/10.33366/bs.v17i1.580 [Indonesian]

Kammann, C., Glaser, B., \& Schmidt, H. P. (2016). Combining biochar and organic amendments. Biochar in European Soils and Agriculture: Science and Practice, April, 136-164. https://doi.org/10.4324/9781315884462-15

Kaya, E. (2018). Pengaruh Kompos Jerami Dan Pupuk NPK Terhadap N-Tersedia Tanah, Serapan-N, Pertumbuhan, Dan Hasil Padi Sawah (Oryza sativa L). Agrologia, 2. https://doi.org/10.30598/a.v2i1.277

[Indonesian]

Nurida. (2014). Potensi Pemanfaatan Biochar untuk Rehabilitasi Lahan Kering di Indonesia. Jurnal Sumberdaya Lahan Edisi Khusus, 57-68. doi: http://dx.doi.org/10.21082/jsdl.v8n3.2014.\%25p [Indonesian]

Pabendon, M. B., Santoso, S. B., dan Subekti, N. A. (2013). Prospek Sorgum Manis sebagai Bahan Baku Bioetanol. Sumarno, Damardjati, D., Syam, M., dan Hermanto. Sorgum Inovasi Teknologi dan Pengembangan. Jakarta: IAARD Press Badan Penelitian dan Pengembangan Pertanian. [Indonesian]

Purwanto, I., Suryono, J.' Sumantri, K. K., Somantri, E., Mulyadi, Suwandi, Jaenudin, Mindawati, Suhaeti, E., Hidayat, E., dan Hidayat, R. (2014).
Petunjuk Teknis Pelaksanaan Penelitian Kesuburan Tanah. Jakarta: IAARD Press Badan Penelitian dan Pengembangan Pertanian. [Indonesian]

Silva, A.F., Ferreira, O., Costa, G., Montijo, N., Mutton, M., \& Mutton, M. (2016). Technological quality of sweet sorghum processed without panicles for ethanol production. Australian Journal of Crop Science, $\quad 10, \quad 1578-1582$. https://doi.org/10.21475/ajcs.2016.10.11.p7697

Sonobe, K., Hattori, T., An, P., Tsuji, W., Eneji, A. E., Kobayashi, S., Kawamura, Y., Tanaka, K., \& Inanaga, S. (2010). Effect of Silicon Application on Sorghum Root Responses to Water Stress. Journal of Plant Nutrition, 34(1), 71-82. https://doi.org/10.1080/01904167.2011.53136.

Sukartono, Suwardji, dan Ridwan. (2015). Pemanfaatan Kompos dan Biochar sebagai Bahan Pembenah Tanah Lahan Bekas Penambangan Batu Apung di Pulau Lombok. Agronomi Teknologi Dan Sosial Ekonomi Pertanian, 25(1), 1-11. Retrieved from https://agroteksos.unram.ac.id/index.php/Agr oteksos/article/view/49. [Indonesian]

Suwardji., Ma'shum, M., Apliza, D., Wargadalam, V. J., dan Adilla, I. (2019). Influence of Silikat and Manure on Growth, Brix Content, and Yield of Sweet sorghum on Dryland Sandy Soil of North Lombok. Paper Presented at International Soil Science Conference August 5-7. Trans Hotel Bandung

Tang, J., Zhu, W., Kookana, R., \& Katayama, A. (2013). Characteristics of biochar and its application in remediation of contaminated soil. Journal of Bioscience and Bioengineering, 116(6), 653-659. https://doi.org/https://doi.org/10.1016/i.jbiosc .2013 .05 .035

Zubair, A. (2016). Sorgum Tanaman Multi Manfaat. Bandung: Unpad Press. [Indonesian] 